\title{
Correction to: Bio-economics of Indian hybrid Bt cotton and farmer suicides
}

\author{
Andrew Paul Gutierrez ${ }^{1,2^{*}} \mathbb{D}$, Luigi Ponti ${ }^{1,3}$, Keshav R. Kranthi $^{4}$, Johann Baumgärtner ${ }^{1}$, Peter. E. Kenmore ${ }^{1}$,
} Gianni Gilioli ${ }^{1,5}$, Antonio Boggia ${ }^{1,6}$, Jose Ricardo Cure ${ }^{1,7}$ and Daniel Rodríguez ${ }^{1,7}$

\section{Correction to: Environ Sci Eur (2020) 32:139}

https://doi.org/10.1186/s12302-020-00406-6

Following publication of the original article [1], the symbol for rupee (₹) was changed to delta $(\Delta)$ in several places. It has been corrected with this correction.

The original article has been corrected.

\section{Author details}

${ }^{1}$ Center for the Analysis of Sustainable Agricultural Systems, 37 Arlington Ave, Kensington, CA 94707, USA. ${ }^{2}$ Division of Ecosystem Science, College of Natural Resources, University of California, Berkeley, CA 94720-3114, USA. ${ }^{3}$ Agenzia Nazionale per le Nuove Tecnologie, I'Energia e lo Sviluppo Economico Sostenibile (ENEA), Centro Ricerche Casaccia, Via Anguillarese 301, 00123 Roma, Italy. ${ }^{4}$ International Cotton Advisory Committee, 1629 K Street, Washington, NWDC 20006, USA. ${ }^{5}$ Dipartimento di Medicina Molecolare e Traslazionale, Università di Brescia, Viale Europa 11, 25123 Brescia, Italy. ${ }^{6}$ Department of Agricultural, Environmental and Food Sciences, University of Perugia, Borgo XX Giugno, 74, 06121 Perugia, Italy. ${ }^{7}$ Facultad de Ciencias Básicas y Aplicadas, Universidad Militar Nueva Granada, Cr. 11 No. 101-80, Bogotá, Colombia.

Accepted: 3 December 2020

Published online: 29 December 2020

\section{Reference}

1. Gutierrez AP, Ponti L, Kranthi KR, Baumgärtner J, Kenmore PE, Gilioli G, Boggia A, Cure JR, Rodríguez D (2020) Bio-economics of Indian hybrid Bt cotton and farmer suicides. Environ Sci Eur 32:139. https://doi. org/10.1186/s12302-020-00406-6

\section{Publisher's Note}

Springer Nature remains neutral with regard to jurisdictional claims in published maps and institutional affiliations.

The original article can be found online at https://doi.org/10.1186/s1230 2-020-00406-6.

*Correspondence: CASAS.Global@berkeley.edu

${ }^{1}$ Center for the Analysis of Sustainable Agricultural Systems, 37 Arlington

Ave, Kensington, CA 94707, USA

Full list of author information is available at the end of the article

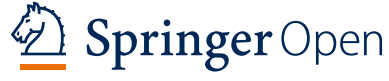

(c) The Author(s) 2020. This article is licensed under a Creative Commons Attribution 4.0 International License, which permits use, sharing, adaptation, distribution and reproduction in any medium or format, as long as you give appropriate credit to the original author(s) and the source, provide a link to the Creative Commons licence, and indicate if changes were made. The images or other third party material in this article are included in the article's Creative Commons licence, unless indicated otherwise in a credit line to the material. If material is not included in the article's Creative Commons licence and your intended use is not permitted by statutory regulation or exceeds the permitted use, you will need to obtain permission directly from the copyright holder. To view a copy of this licence, visit http://creativecommons.org/licenses/by/4.0\%. 